\title{
Replication of Coliphage M-13
}

\section{Intracellular Deoxyribonucleic Acid Forms Associated with M-13 Infection of Mitomycin C-treated Cells}

\author{
LYLE R. BROWN² AND C. E. DOWELL \\ Department of Microbiology, Tulane University School of Medicine, New Orleans, Louisiana 70112, \\ and Department of Bacteriology, University of California, Davis, California 95616
}

Received for publication 14 June 1968

\begin{abstract}
Intracellular deoxyribonucleic acid (DNA) forms associated with bacteriophage M-13 infection have been isolated and characterized. Escherichia coli HF4704 (F⿻ $h \mathrm{cr}^{-}$, thy $^{-}$) cells were treated with mitomycin C to inhibit host-cell DNA synthesis and were then infected with phage M-13. This treatment permitted radioactive labeling of phage-specific DNA forms with ${ }^{3} \mathrm{H}$-thymine. These labeled DNA components were characterized by sucrose density sedimentation and equilibrium density gradient centrifugation in neutral and ethidium bromide $\mathrm{CsCl}$ gradient. Two double-stranded circular forms were found with properties analogous to the replicative form I and replicative form II of $\phi$ X174. A third component, identified as single-stranded DNA, was isolated in some samples removed 45 min after phage synthesis was initiated.
\end{abstract}

M-13 is one of the several filamentous phages that contain single-stranded (20) and probably circular (16) deoxyribonucleic acid (DNA) similar in size and configuration to the DNA of the small icosohedral phage $\phi X 174$. The replication of $\phi X 174$ has been the subject of extensive investigation $(10,11)$ and intracellular forms associated with $\phi X 174$ replication are well documented (3). The only known reports on the intracellular DNA forms of M-13 are studies by Ray, Bscheider, and Hofschneider (19) and by Ray, Preuss, and Hofschneider (20). The first authors isolated the replicative form (RF) of M-13 from infected cells by fractionation on a methylated albumin-kieselguhr column. This RF was biologically active. The second authors demonstrated that M-13 RF had supercoiled structure similar to polyoma DNA (27) and $\phi X 174 \mathrm{RF}$ (3).

Several important differences between $\phi$ X174 and M-13 replication are known. M-13, like most of the filamentous phages, is distinguished by the unusual property of release from the host cell without cell lysis while the cells continue to grow and divide at an exponential rate (21). $\phi$ X174 not only lyses the cell at the end of its replicative cycle, but also has been recently shown to cause the cessation of host DNA synthesis (12). The latter

\footnotetext{
${ }^{1}$ Taken from a dissertation submitted by L. R. B. to Tulane University in partial fulfillment of the requirement for the Ph.D. degree, May 1968.

2 Present Address: Department of Bacteriology, University of California, Davis 95616.
}

is obviously not true for M-13 infection. Further, $\phi \mathrm{X} 174$ matures and is released from the host cell at a linear rate according to Denhardt and Sinsheimer (4), whereas studies on M-13 indicate that early in a synchronized infection the rate of release from the cells is not linear but exponential (2).

These major differences between $\phi \mathrm{X} 174$ and M-13 replication and the ubiquity of filamentous phages prompted the present study on intracellular DNA forms associated with M-13 replication. Twelve filamentous phages have been described; their host cells include three bacterial genera $(8$, $25,17)$.

The mitomycin $\mathrm{C}$ technique used for the specific radioactive labeling of viral DNA components requires the use of host cells deficient in the usual host-cell reactivation systems. This technique was developed by Lindqvist and Sinsheimer to study the replication of $\phi \mathrm{X} 174$ (13). We have employed it, with slight modifications, to study M-13 replication.

\section{Materials AND Methods}

Media. KC broth, top agar, bottom agar, Denhardt's starvation buffer, dilution buffer, starvation buffer, TPG-2A, and TPG-3A have been described $(2,4,5,22)$. Standard saline citrate $(0.15 \mathrm{M} \mathrm{NaCl}$ and $0.015 \mathrm{M}$ trisodium citrate, SSC) was prepared at various ionic strengths $(0.1 \times \mathrm{SSC}=0.015 \mathrm{M} \mathrm{NaCl}$ and $0.0015 \mathrm{M}$ trisodium citrate). All media and buffers used with thymine-requiring strains were supplemented with a minimum of $2 \mu \mathrm{g}$ of thymine per $\mathrm{ml}$. 
Chemicals and radiochemicals. Mitomycin $\mathrm{C}$ was purchased from the Nutritional Biochemicals Corp., Cleveland, Ohio. Ethidium bromide was a gift from Boots Pure Drug Co., Ltd. Radioactive methyl- ${ }^{3} \mathrm{H}-$ thymine was purchased from New England Nuclear Corp., Boston, Mass., and adenine- $8-{ }^{14} C$ was obtained from Schwartz Bio Research Inc., Orangeburg, N.Y.

Bacteria. Escherichia coli $\mathrm{S}-26$ has been described previously (6). E. coli C-406 is a strain originally derived by $\mathrm{G}$. Bertani from $E$. coli $\mathrm{C}$ and requires purine, arginine, and tryptophan. It was kindly supplied by R. L. Sinsheimer, California Institute of Technology, Pasadena. E. coli $\mathrm{HF} 4704 \mathrm{~F}^{+}$was derived from strain HF4704 described by Lindqvist and Sinsheimer (13) by $\mathrm{F}^{+}$factor transfer from $E$. coli 58-161 $\mathrm{F}^{+}$. E. coli 58-161 $\mathrm{F}^{+}$was obtained from Joseph Gots, University of Pennsylvania, Philadelphia.

Preparation of ${ }^{14} \mathrm{C} \phi X 174 \mathrm{am} 3$ and ${ }^{14} \mathrm{C} \phi X 174 \mathrm{am} 3$ $D N A$. E . coli $\mathrm{C}-406$ was grown to a cell density of $3 \times 10^{8}$ to $4 \times 10^{8}$ in TPG-2A plus $6.6 \mu \mathrm{g}$ of adenine per $\mathrm{ml}$. Cells were centrifuged, washed, and suspended in Denhardt's starvation buffer. The cells were starved for $75 \mathrm{~min}$ at $37 \mathrm{C}$ and infected with $\phi \mathrm{X} 174$ $a m^{3}$ (a lysis-defective mutant) at a multiplicity of infection of 3. After a 20 -min period of infection, the culture was sedimented and suspended in TPG-2A supplemented with $2 \mu \mathrm{c}$ of adenine- $-8{ }^{14} \mathrm{C}$ per ml plus $6.6 \mu \mathrm{g}$ of cold adenine per $\mathrm{ml}$. The cells were incubated for 180 to $210 \mathrm{~min}$ at $37 \mathrm{C}$ with aeration. They were then spun and suspended in $1.5 \mathrm{ml}$ of $0.033 \mathrm{M}$ tris(hydroxymethyl)aminomethane (Tris) buffer, $p \mathbf{H}$ $8.1 ; 0.1 \mathrm{ml}$ of lysozyme $(2 \mathrm{mg} / \mathrm{ml})$ and $0.15 \mathrm{ml}$ of $0.8 \%$ Versene were added. After $3 \mathrm{~min}$, the cells were frozen and thawed six times, $2.5 \mathrm{ml}$ of saturated sodium tetraborate was added to elute the phage, and the mixture was allowed to stand overnight. The cell debris was removed by centrifugation at $12,100 \times g$ for $30 \mathrm{~min}$, solid $\mathrm{CsCl}$ (Harshaw optical grade at $0.625 \mathrm{~g} / \mathrm{g}$ ) was added to the supernatant fluid to give a final density of approximately $1.41 \mathrm{~g} / \mathrm{ml}$. The $\mathrm{CsCl}$ solution was then centrifuged in a Spinco model L2$\mathrm{HV}$ ultracentrifuge for $20 \mathrm{hr}$ at $5 \mathrm{C}$ in an SW-39 rotor at $37,000 \mathrm{rev} / \mathrm{min}$. The equilibrium density gradient thus formed was fractionated by using a Beckman fractionating system. The high-titer phage fractions were pooled, and a second density gradient was prepared and collected in the same manner. The hightiter fractions were again pooled, $2.5 \mathrm{ml}$ of $0.1 \mathrm{M}$ borate was added, and the phage were dialyzed against four exchanges ( $>100$ volumes) of $0.1 \mathrm{M}$ borate. Assays of radioactivity and of plaque forming units showed $5.5 \times 10^{-5}$ counts per min per phage.

A volume of redistilled phenol equilibrated with 0.1 M sodium tetraborate was brought to $70 \mathrm{C} \mathrm{(7).} \mathrm{The}$ phage sample was also brought to $70 \mathrm{C}$ after the addition of $0.1 \mathrm{mg}$ of albumin (from a $30 \%$ solution of bovine serum albumin, Armour Pharmaceutical Co.) per $\mathrm{ml}$ as a protein carrier. The phenol and virus were mixed on a Vortex mixer for $3 \mathrm{~min}$. The mixture was cooled to room temperature and spun at 1,000 $\times$ $g$ for $4 \mathrm{~min}$. The aqueous layer was removed, and this layer was extracted two more times at room temperature with one volume of phenol. Each phenol layer was then serially extracted with $0.5 \mathrm{ml}$ of $0.1 \mathrm{M}$ sodium tetraborate and the aqueous layers were combined. To remove residual phenol, five extractions with one volume of ether were carried out at $0 \mathrm{C}$. The remaining ether was removed by bubbling nitrogen through the solution at $0 \mathrm{C}$.

Preparation of ${ }^{3} \mathrm{H}$-labeled $\mathrm{M}$-13. E. coli HF4704 $\mathrm{F}^{+}$ was grown in TPG-3A plus $2 \mu \mathrm{g}$ of thymine per $\mathrm{ml}$ to a concentration of about $5 \times 10^{8}$. A 10-ml sample was removed, centrifuged at $12,100 \times g$, and the sediment was suspended in $1 \mathrm{ml}$ of TPG-3A plus thymine. Purified M-13 phage was added to a multiplicity of infection of 1 , and the mixture was incubated for 30 min at $37 \mathrm{C}$ with light aeration. The culture was then centrifuged at $12,100 \times g$ and washed with $10 \mathrm{ml}$ of cold TPG-3A; the cells were then suspended in $1 \mathrm{ml}$ of cold TPG-3A. An $0.5-\mathrm{ml}$ amount was used to inoculate $40 \mathrm{ml}$ of prewarmed TPG-3A containing 1 mc of methyl- ${ }^{3} \mathrm{H}$-thymine (New England Nuclear specific activity, $16.7 \mathrm{c} / \mathrm{mm}$ ) and supplemented with $2 \mu \mathrm{g}$ of cold thymine per $\mathrm{ml}$. The culture was incubated at $37 \mathrm{C}$ until a cell density of about $4 \times 10^{9}$ to $6 \times$ $10^{9}$ was reached, then spun at $12,500 \times g$ for $20 \mathrm{~min}$ to remove cells. The supernatant fluid was spun in the no. 30 rotor of a Spinco model L2-HV centrifuge at $27,000 \mathrm{rev} / \mathrm{min}$ for $16 \mathrm{hr}$ at $5 \mathrm{C}$. The small, bluish sediment from two tubes was suspended in a total of $4 \mathrm{ml}$ of dilution buffer and spun in a Spinco 50 rotor at $5 \mathrm{C}$ for $6 \mathrm{hr}$ at $47,000 \mathrm{rev} / \mathrm{min}$. The resulting sediment was suspended in $3 \mathrm{ml}$ of dilution buffer to which was added $0.46 \mathrm{~g} / \mathrm{g}$ of optical grade $\mathrm{CsCl}$ to give a mean density of $1.309 \mathrm{~g} / \mathrm{ml}$.

A density gradient was formed by centrifugation at $37,000 \mathrm{rev} / \mathrm{min}$ in a Spinco SW-39 rotor at $5 \mathrm{C}$ for $30 \mathrm{hr}$, yielding a visible band of phage slightly less than one-half the distance from the bottom of the tube. The gradient was fractionated, and the band of phage was collected and further purified by an additional density gradient centrifugation. The gradient was fractionated into vials containing $1 \mathrm{ml}$ of dilution buffer, and the fraction in which the visible band of phage had been collected was exhaustively dialyzed against five to eight changes of $>100$ volumes of dilution buffer. Assays of the phage suspension for radioactivity and plaque-forming units showed 1.5 $\times 10^{-6}$ counts per min per plaque-forming unit.

Extraction of the ${ }^{3} \mathrm{H}-\mathrm{DNA}$. Single-stranded ${ }^{3} \mathrm{H}-$ labeled M-13 DNA was extracted three times with cold phenol, rather than the hot phenol method described for preparation of ${ }^{14} \mathrm{C} \phi \mathrm{X} 174 \mathrm{am} 3 \mathrm{DNA}$. Bovine serum albumin was not added, but in all other respects the procedure was identical.

Mitomycin $C$ treatment of $\mathrm{HF}_{4704 \mathrm{~F}^{+}}$and phage infection. E. coli $\mathrm{HF} 4704 \mathrm{~F}^{+}$, which had been grown to a concentration of about $10^{9}$ cells $/ \mathrm{ml}$ in $\mathrm{KC}$ broth, spun at $12,500 \times g$ for $10 \mathrm{~min}$, suspended in 0.1 volume of starvation buffer, then aerated at $37 \mathrm{C}$ for $30 \mathrm{~min}$. A $50-\mu \mathrm{g}$ amount of mitomycin $\mathrm{C}$ per $\mathrm{ml}$ (calculated from the weight of the impure drug supplied by the manufacturer) was added, and the cells were incubated for an additional $10 \mathrm{~min}$ without aeration. These cells were then spun as before, washed three times with cold starvation buffer, and resuspended at a cell concentration of about $10^{10}$ cells $/ \mathrm{ml}$ in 
starvation buffer. Phage was added at an input multiplicity of infection of 10 and allowed to adsorb for $30 \mathrm{~min}$. The infected cells were then centrifuged and washed three times to remove unadsorbed phage. Vigorous agitation was avoided in suspending the bacteria during the washing procedure to prevent the removal of adsorbed phage. The bacterial cells were suspended in prewarmed broth for incorporation and uptake experiments.

Isolation of intracellular DNA. At the time desired, 20-ml samples of the culture (cell density of about $3 \times$ $\left.10^{8}\right)$ were removed and rapidly chilled in a dry-ice/ acetone bath. Caution was exercised to prevent freezing the samples. The samples were then immediately centrifuged to prevent readsorption of

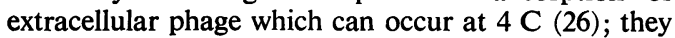
were then washed, recentrifuged, and suspended with $10 \mathrm{ml}$ of ice-cold $0.033 \mathrm{M}$ Tris buffer $(p \mathrm{H} \mathrm{8.1)}$ three times. Between each wash, the cells were thoroughly mixed on a Vortex mixer. Finally, they were suspended in $1.5 \mathrm{ml}$ of $0.033 \mathrm{M}$ Tris $(\mathrm{pH} \mathrm{8.1)}$ and frozen. This material was thawed, and $0.1 \mathrm{ml}$ of lysozyme $(2 \mathrm{mg} /$ $\mathrm{ml}$ ) was added to each sample. After $2 \mathrm{~min}, 0.15 \mathrm{ml}$ of $0.8 \%$ Versene was added and the samples were mixed by hand for $3 \mathrm{~min}$. The cells were lysed by freezing and thawing three times.

Deproteinization and precipitation of the samples was essentially the same as described by Dowell and Sinsheimer (5), except that some samples were dialyzed against four to six changes of $0.1 \mathrm{M} \mathrm{NaCl}$, and all samples were precipitated twice.

Assay for biological activity of $\phi X 174$ DNA. Biological activity was measured by the spheroplast technique of Guthrie and Sinsheimer (7).

\section{RESUltS}

Effect of mitomycin on starved E. coli HF4704 $\mathrm{F}^{+}$. A culture was grown to about $10^{9}$ cells $/ \mathrm{ml}$, concentrated 10 times by centrifugation and suspension in 0.1 volume of starvation buffer, and starved for $30 \mathrm{~min}$; mitomycin $\mathrm{C}$ was added to give a final concentration of $50 \mu \mathrm{g} / \mathrm{ml}$. Samples were removed and diluted initially $1: 100$ at the times indicated in Table 1 ; they were then further diluted as rapidly as possible to reduce the residual drug concentration before plating and incubation

TABLE 1. Effect of mitomycin $C$ on E. coli $\mathrm{HF} 4704 \mathrm{~F}^{+}$

\begin{tabular}{c|c|c}
\hline Time & Viable cells $/ \mathrm{ml}$ & Surviving fraction \\
\cline { 2 - 3 } $\min$ & & \\
0.0 & $1.2 \times 10^{10}$ & 1.0 \\
0.5 & $2.7 \times 10^{7}$ & $2.3 \times 10^{-2}$ \\
1.0 & $2.7 \times 10^{6}$ & $2.3 \times 10^{-3}$ \\
1.5 & $8.9 \times 10^{4}$ & $7.4 \times 10^{-6}$ \\
2.0 & $2.9 \times 10^{4}$ & $2.4 \times 10^{-6}$ \\
2.5 & $1.9 \times 10^{4}$ & $1.6 \times 10^{-6}$ \\
6.0 & $2.5 \times 10^{3}$ & $2.1 \times 10^{-7}$ \\
10.0 & $1.3 \times 10^{3}$ & $1.1 \times 10^{-7}$ \\
\hline
\end{tabular}

at $37 \mathrm{C}$ for $48 \mathrm{hr}$. The colonies were counted, and the results were as shown in Table 1. A 10-min exposure to the drug was sufficient to reduce the surviving fraction to about $10^{-7}$. In similar experiments, treated cells were centrifuged, washed three times, and suspended in $\mathrm{KC}$ broth at $37 \mathrm{C}$ for $60 \mathrm{~min}$. There was no detectable recovery of the ability to form colonies.

Radioactive uptake and incorporation of ${ }^{3} \mathrm{H}$ thymine in M-13-infected cells. To measure the incorporation of ${ }^{3} \mathrm{H}$-thymine into mitomycintreated cells that had been infected with $\mathrm{M}-13$, such cells were treated, infected, and then suspended in $\mathrm{KC}$ broth (at $37 \mathrm{C}$ ) containing $20 \mu \mathrm{c}$ of methyl- ${ }^{3} \mathrm{H}$-thymine per $\mathrm{ml}$. At time intervals after infection, $0.1-\mathrm{ml}$ samples were removed and added to $1 \mathrm{ml}$ of cold $10 \%$ trichloroacetic acid. The precipitable material was collected and washed on membrane filters which were dried, and the radioactivity was measured. Alternatively, 20-ml samples were removed, the cells were centrifuged and washed three times, and the DNA was extracted. The DNA was precipitated twice with isopropanol and redissolved in $0.1 \mathrm{M} \mathrm{NaCl}$, and the radioactivity was measured. Results from two separate experiments are illustrated in Fig. 1. Significant incorporation of radioactivity into DNA by cells infected with M-13 was shown with both techniques. Uninfected cells showed from 1 to $10 \%$ of the incorporation of infected cells.

Other experiments, in which cell samples were washed and taken up in counting fluid with a suspending agent (Cabosil), gave comparable results. These counts, however, represented uptake by the cells as well as incorporation. The relation between the time of phage release and uptake of tritium is shown in Fig. 3. Infected cells showed an increase in counts within the first 5 min after being suspended in the radioactive medium.

Since commercial tryptone contained some thymine, the specific activity of the medium and uptake rates could not be calculated.

Growth of $M-13$ in E. coli HF4704 $\mathrm{F}^{+}$. Figure 2 shows a single-step growth curve of coliphage M-13 in host cells that were starved and infected according to the procedure outlined for mitomycin treatment. To the control cell culture was added a volume of starvation buffer equivalent to the volume of mitomycin $\mathrm{C}$ solution normally employed. The latent period of about $10 \mathrm{~min}$ was equivalent to that observed in other cell lines. The total phage production was somewhat less. HF4704 $\mathrm{F}^{+}$cells produced 60 to 70 phage per infected cell in $60 \mathrm{~min}$, or about one-third of that observed for $E$. coli S-26 (2).

A similar growth curve was observed in 


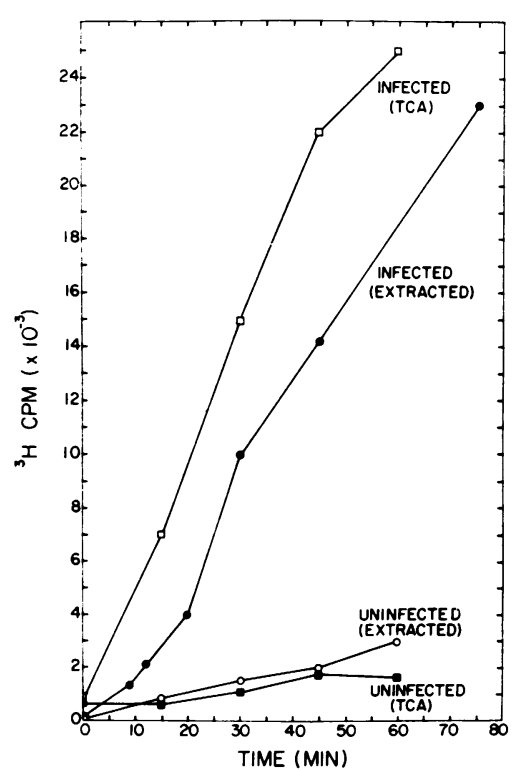

FIG. 1. Incorporation of ${ }^{3} \mathrm{H}$-labeled thymine by mitomycin $C$-treated cells infected with coliphage $M-13$. E. coli HF4704 $\mathrm{F}^{+}$was grown to about $10^{9}$ cells $/ \mathrm{ml}$, starved for $30 \mathrm{~min}$, treated with $50 \mu \mathrm{g}$ of mitomycin per $\mathrm{ml}$ for $10 \mathrm{~min}$, and then infected with M-13. The cells were suspended in $\mathrm{KC}$ broth $+20 \mu \mathrm{c}$ of tritiated thymine per $\mathrm{ml}$. At various times, samples were removed and the DNA was extracted and assayed for radioactivity, or the samples were added to trichloracetic acid, and the insoluble material was collected on membrane filters and assayed for radioactivity. The extracted counts and trichloroacetic acid precipitable counts represent separate experiments.

mitomycin-treated cells (Fig. 3). Mitomycin C-treated cells produced about 30 phage per infective center, about one-half the number produced by the nontreated cells. The 10-min latent period was variable; in some experiments it was extended by as much as $5 \mathrm{~min}$. Thus, growth curves were required to control all experiments in which the mitomycin treatment was used. The reason for this variability was not determined. Unlike the nontreated cells, the host cells treated with mitomycin $\mathrm{C}$ ceased phage production about 60 min after suspension in fresh medium.

Other experiments indicated that growth media and the length of starvation prior to drug treatment also affected phage production. Phage was not produced when cells were grown in minimal medium or in TPG and suspended after drug treatment in minimal, TPG, or KC broth. Only when cells were grown and resuspended in broth were phage produced. When cells were starved for $60 \mathrm{~min}$ rather than the $30 \mathrm{~min}$ we routinely employed, phage production was reduced 50 to $75 \%$.

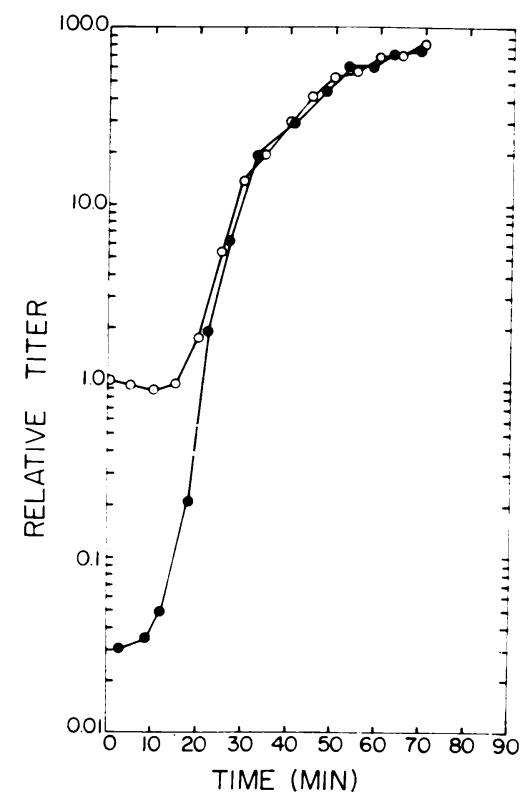

FIG. 2. Growth of M-13 in HF4704 $\mathrm{F}^{+}$. Cells were grown and infected as described, except for mitomycin treatment, which was omitted. These cells were resuspended and the intracellular and infective centers were assayed. Titer is shown as relative to initial number of infective centers. Symbols: $\bigcirc$, infective centers; $\bigcirc$, intracellular phage.

Longer starvation periods resulted in little or no phage production.

Sedimentation of intracellular DNA components associated with $M-13$ infection. Since it had been shown that mitomycin-treated cells incorporated ${ }^{3} \mathrm{H}$ into DNA under conditions that produced significant amounts of phage, a series of experiments was performed to isolate and characterize the intracellular ${ }^{3} \mathrm{H}$-labeled components associated with M-13 infection. Treated cells were infected with M-13 and then suspended in KC broth containing $20 \mu \mathrm{c}$ of tritiated thymine per $\mathrm{ml}$. At time intervals, samples were removed and the DNA was extracted with phenol. Figures 4 to 7 show the profile of tritium counts in intracellular DNA extracts sedimented under various ionic conditions in a 5 to $20 \%$ linear sucrose gradient for $5.5 \mathrm{hr}$. Two major tritium-labeled components were observed, components I (the faster-sedimenting peak) and component II (the slower-sedimenting peak). Neither of these components showed the sedimentation rate dependence on ionic strength characteristic of the singlestranded, ${ }^{14} \mathrm{C}$-labeled $\phi \mathrm{X} 174 \mathrm{am}^{3}$ DNA marker. At high ionic strength, the second component was not well resolved, and in $0.5 \times \mathrm{SSC}$ the marker 


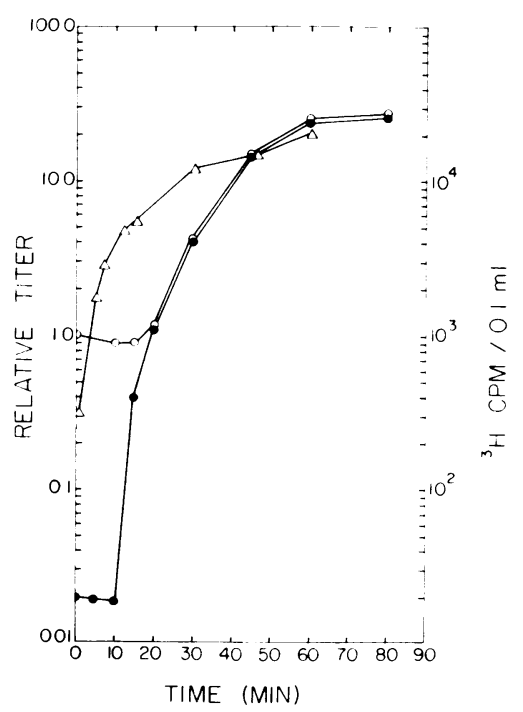

FIG. 3. Growth of $M-13$ in mitomycin C-treated $\mathrm{hcr}^{-}$E. coli cells. Cells were infected as described. After resuspending the cells in KC broth containing ${ }^{3}$ H-labeled thymine, samples were removed, and infective centers or intracellular assays were performed. Some cell samples were washed and suspended directly in counting fluids, and the radioactivity was measured. Symbols: O, infective centers; $\mathbf{O}$, intracellular assay; $\triangle$, uptake of ${ }^{3} \mathrm{H}$-thymine by infected cells.

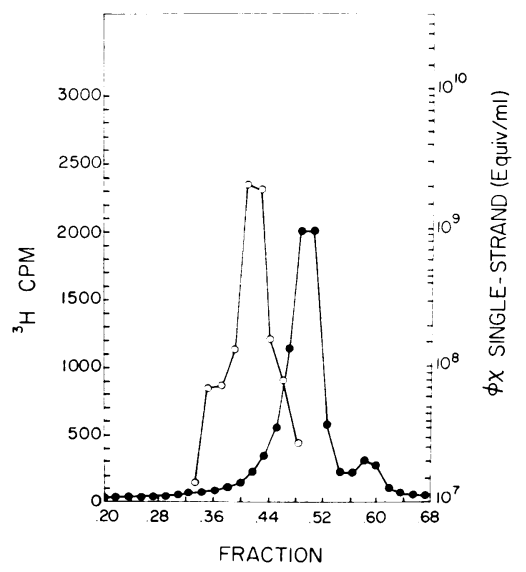

FIG. 4. Sucrose density gradient sedimentation of intracellular DNA components in 0.5 . 1 sodium chloride and $0.05 \mathrm{M}$ sodium citrate. A 40-min intracellular $D N A$ sample (100 $\mu$ liters) and $\phi X 174$ single-stranded DNA (25 uliters) were layered onto a 5 to $20 \%$ linear sucrose gradient and centrifuged for $5.5 \mathrm{hr}$ in an $S W-39$ rotor at 37,000 rev/min. Fractions were collected and assayed for biological activity of the marker DNA and ${ }^{3} \mathrm{H}$ radioactivity in intracellular DNA. Symbols:,${ }^{3} \mathrm{H}$ labeled intracellular DNA; $\bigcirc$, biological activity of $\phi X 174$ single-stranded marker DNA. sedimented at the same rate as component I. Both major tritium-labeled components and the singlestranded marker were well resolved in $1.0187 \mathrm{M}$ $\mathrm{NaCl}$ plus $0.01187 \mathrm{M}$ sodium citrate $(0.118 \times$

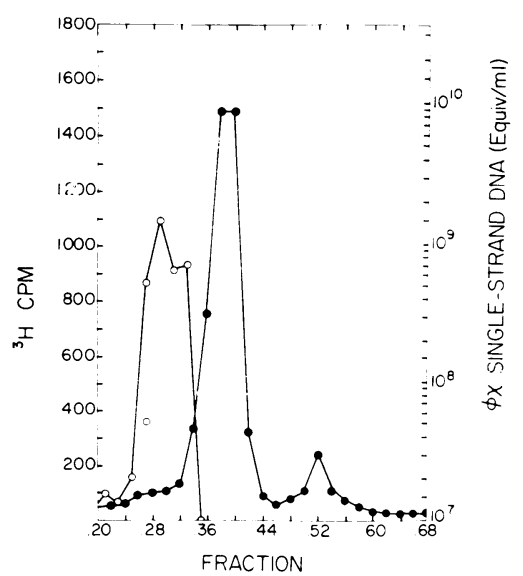

FIG. 5. Sucrose density gradient sedimentation of intracellular DNA components in 0.1 m sodium chloride and $0.01 \mathrm{M}$ sodium citrate. The sedimentation analysis of a 40-min sample was identical to that described in Fig. 4, except for the change in ionic conditions. Fractions that are not shown did not contain significant amounts of radioactivity or $\phi X 174$ marker DNA. Symbols: ${ }^{3} \mathrm{H}$-labeled DNA; $\bigcirc$, biological activity of $\phi X 174$ single-stranded DNA marker.

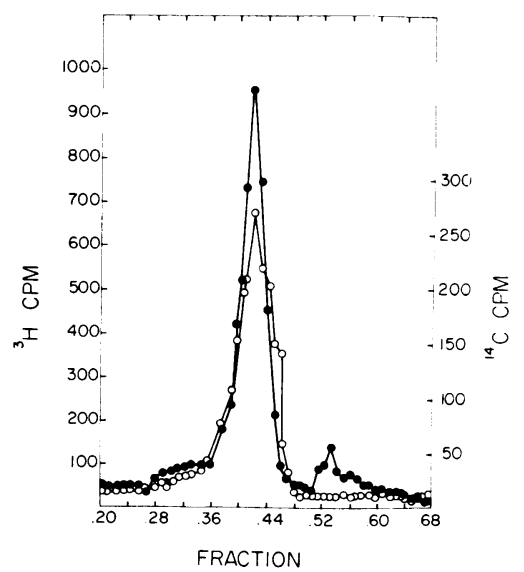

Fig. 6. Sucrose density gradient sedimentation of intracellular DNA components in 0.075 M sodium chloride and $0.0075 \mathrm{M}$ sodium citrate. A 40-min intracellular, ${ }^{3} \mathrm{H}$-labeled DNA sample (100 uliters) was sedimented with a ${ }^{14} \mathrm{C} \phi X 174$ am3 single-stranded DNA marker (25 $\mu$ liters) in a 5 to $20 \%$ sucrose gradient. After layering, the sample was spun for $5.5 \mathrm{hr}$ at 37,000 $\mathrm{rev} / \mathrm{min}$ in a Spinco $S W-39$ rotor, collected, and then assayed for radioactivity. Symbols:,${ }^{3} \mathrm{H}$-labeled intracellular $D N A ; O,{ }^{14} \mathrm{C}$-labeled $\phi X 174$ am3 singlestranded DNA. 
SSC). Therefore, those conditions were chosen for further analysis.

Figure 8 shows the relative sedimentation patterns obtained in 0.118 SSC with ${ }^{3} \mathrm{H}$-labeled M-13

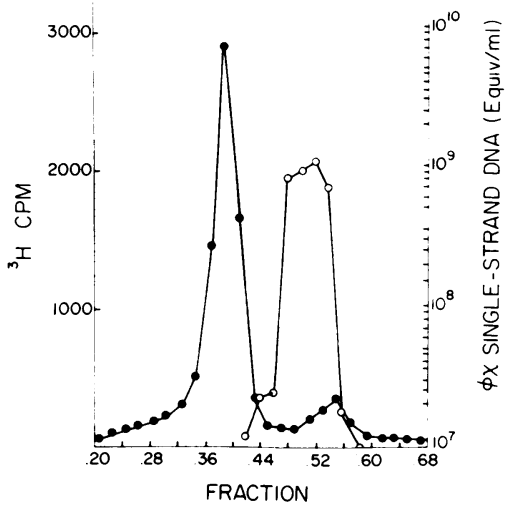

FIG. 7. Sucrose density gradient sedimentation of an intracellular DNA sample in 0.01 M sodium chloride and 0.01 y sodium citrate. A 40-min intracellular DNA sample (100 uliters) and $\phi X 174$ single-stranded DNA (25 uliters) were layered onto a 5 to $20 \%$ linear sucrose gradient and centrifuged for $5.5 \mathrm{hr}$ in a Spinco $S W-34$ rotor at 37,000 rev/min. Fractions were collected and assayed for biological activity of marker DNA and for ${ }^{3} \mathrm{H}$ radioactivity. Symbols: ${ }^{3} \mathrm{H}$-labeled intracellular $D N A ; \bigcirc$, biological activity of $\phi X 174$ single-stranded $D N A$. viral DNA and ${ }^{1+} \mathrm{C}-\phi \mathrm{X} 174 \mathrm{am} 3$ single-stranded DNA. Under these conditions, M-13 DNA sedimented slightly faster than the $\phi \times 174$ singlestrand marker.

Equilibrium centrifugation in $\mathrm{CsCl}$ at neutral $p H$. Intracellular ${ }^{3} \mathrm{H}$-labeled DNA, extracted from a sample removed $40 \mathrm{~min}$ after infection, was spun in a Spinco ultracentrifuge at $37,000 \mathrm{rev}$ min in the SW-39 rotor for $30 \mathrm{hr}$ at $5 \mathrm{C}$ in a $\mathrm{CsCl}$ density gradient (mean density, $1.709 \mathrm{~g} / \mathrm{ml}$ ). This gradient was prepared by the addition of solid $\mathrm{CsCl}$, at 1.30 to $1.31 \mathrm{~g} / \mathrm{g}$, to the SSC buffer containing the DNA. The fractions were collected and assayed for radioactivity (Fig. 9). All of the tritium counts were found in a single peak at a density lighter than that of the single-stranded marker DNA. We believe that this represents M-13 RF, since similar density gradient profiles have been reported for $\phi$ X174 RF (23) and $\phi \mathrm{X} 174$ single-stranded DNA.

Effects of ascorbate treatment on ${ }^{3} \mathrm{H}$-labeled components. Bode (1) has shown that supercoiled double-stranded DNA helixes of $\lambda$ DNA are converted to a nonsupercoiled form by mild treatment with reducing agents which introduce singlestrand breaks in the DNA backbone. The intracellular DNA extracted from cells was incubated with $7 \times 10^{-5} \mathrm{M}$ ascorbate at $37 \mathrm{C}$ for 75 min (Fig. 10). Figure 11 illustrates the results obtained with a control incubated at $37 \mathrm{C}$ without ascorbate. The treated sample showed a large

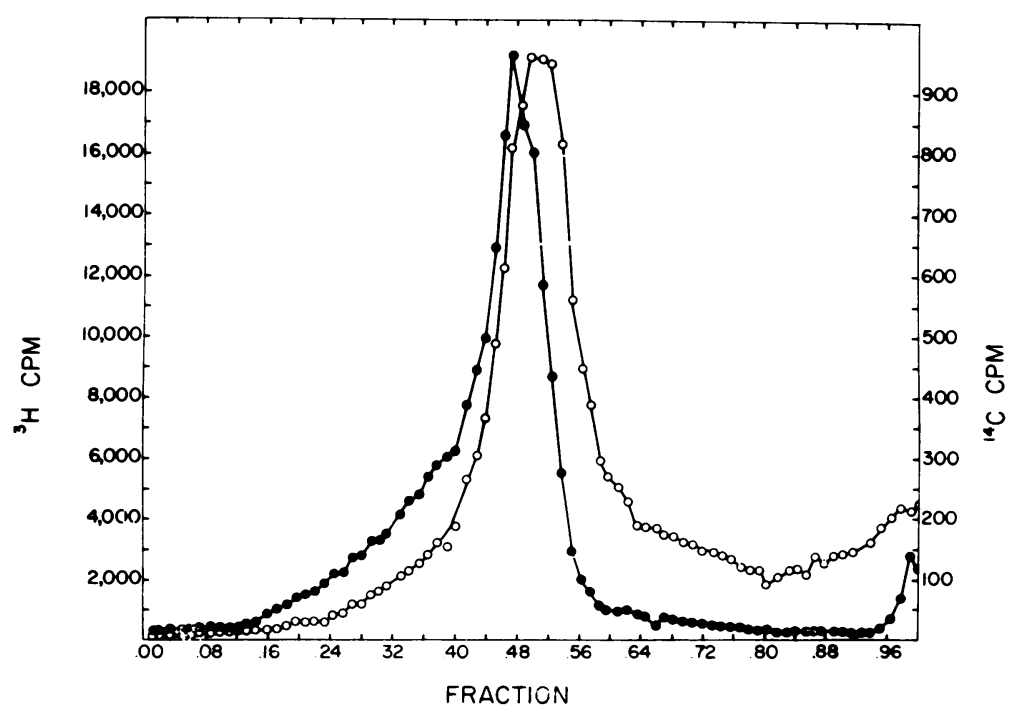

FIG. 8. Sedimentation of M-13 single-stranded DNA. Sucrose density gradient sedimentation of ${ }^{3} \mathrm{H}$-labeled

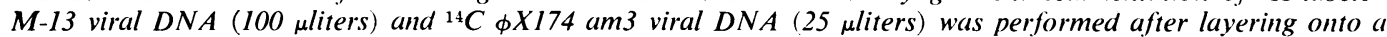
5 to $20^{\circ}$; linear sucrose gradient. The samples were spun at 37,000 rev/min in a Spinco $S W-39 \mathrm{rotor}$ for $5.5 \mathrm{hr}$, fractionated, and assayed for radioactivity. Symbols: O, ${ }^{3} \mathrm{H}$-labeled M-13 DNA; $0,{ }^{1+} \mathrm{C}$-labeled $\phi X I 74$ am. 3 marker DNA. 
decrease in the amount of component I accompanied by a very large increase in the material sedimenting at the position of component II. A third peak of tritium counts was also found at the position of single-stranded DNA. These results

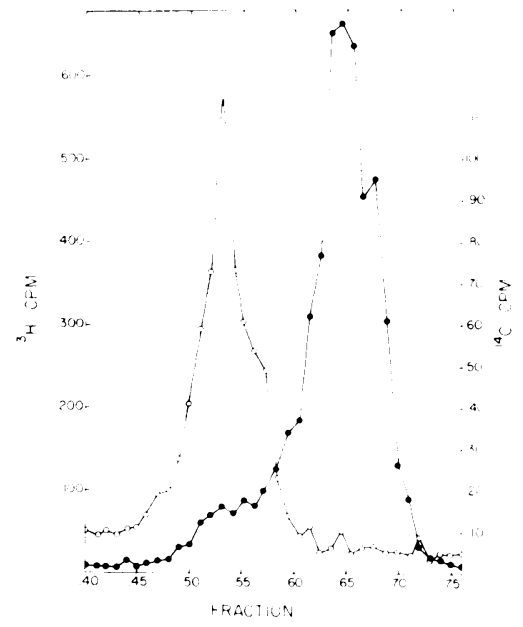

FIG. 9. CsCl equilibrium density gradient centrifugation of intracellular DNA components. A $15-\mathrm{min}{ }^{3} \mathrm{H}$ labeled DNA sample extracted from M-13-infected cells was centrifuged in a CsCl-SSC solution (mean density $=1.709 \mathrm{~g} / \mathrm{ml}$ ) with $a{ }^{14} \mathrm{C} \phi X 174 \mathrm{am} 3$ singlestranded DNA marker for $30 \mathrm{hr}$ at 37,000 rev/min in a Spinco $S W-39$ rotor. Fractions were collected and assayed for radioactivity in a liquid scintillation spectrometer. Symbols:,${ }^{3}$ H-labeled intracellular DNA; $\bigcirc,{ }^{14} C$-labeled $\phi X 174$ am3 single-stranded marker $D N A$. indicated that components I and II were probably analogous to RF I and RF II of $\phi \times 174$. At high ionic strength, component $\mathrm{I}$ has sedimentation profiles similar to the RF supercoiled structure described by Ray et al. (20).

Equilibrium centrifugation in ethidium bromide. Radloff, Bauer, and Vinograd (18) have demonstrated the separation of closed-circular, doublestranded DNA from nicked-circular, doublestranded DNA by using saturating concentrations of the intercalating dye ethidium bromide. Under these conditions, the closed-circular DNA binds less dye than the nicked-circular DNA. Since there is an inverse relationship between the amount of dye bound and the density of the two forms, the closed form was found to band at a denser position in the gradient. Part of an intracellular ${ }^{3} \mathrm{H}$-labeled DNA sample, which contained $14 \%$ of the total counts in component II by sucrose gradient centrifugation analysis, was banded in a $\mathrm{CsCl}$ density gradient of $1.558 \mathrm{~g} / \mathrm{ml}$ in the presence of $100 \mu \mathrm{g}$ of ethidium bromide per ml. Figure 12A shows the profile of tritium counts after fractionation of the gradient formed by $30 \mathrm{hr}$ of centrifugation in an SW-39 rotor at $37,000 \mathrm{rev} / \mathrm{min}$. The position of the "heavy" and "light" components is similar to that observed for polyoma DNA I and II by Radloff et al. (18). Approximately the same ratio of counts was found in the "heavy" to "light" peaks as was shown for components I and II by sucrose gradient analysis. Treatment of a portion of the same intracellular DNA sample for 60 min with $7 \times$ $10^{-5} \mathrm{M}$ ascorbate and similar banding of the

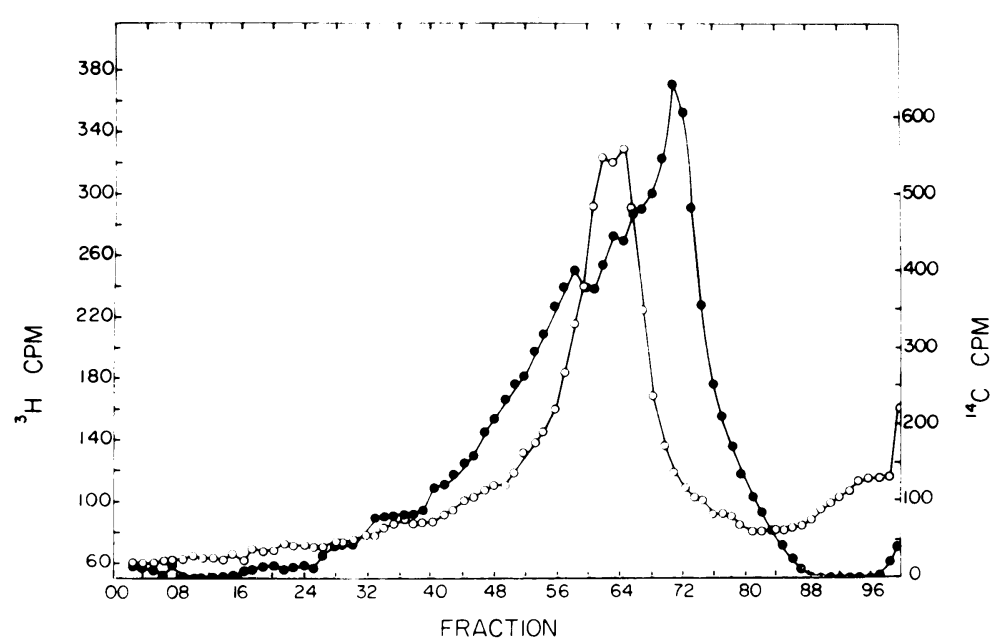

FIG. 10. Ascorbate-treated intracellular DNA. A 40-min intracellular DNA sample was incubated at 37 C for 75 min with $7 \times 10^{-5}$ y ascorbate, layered onto a 10 to 20\%, linear sucrose gradient, and spun at 37,000 rev/ min in a Spinco $S W-39$ rotor for $5.5 \mathrm{hr}$. Fractions were collected and assayed for radioactivity. Symbols: ${ }^{3} \mathrm{H}$-labeled intracellular DNA components; $0,{ }^{1+}$ C-labeled $\phi X 174$ am3 single-stranded DNA. 


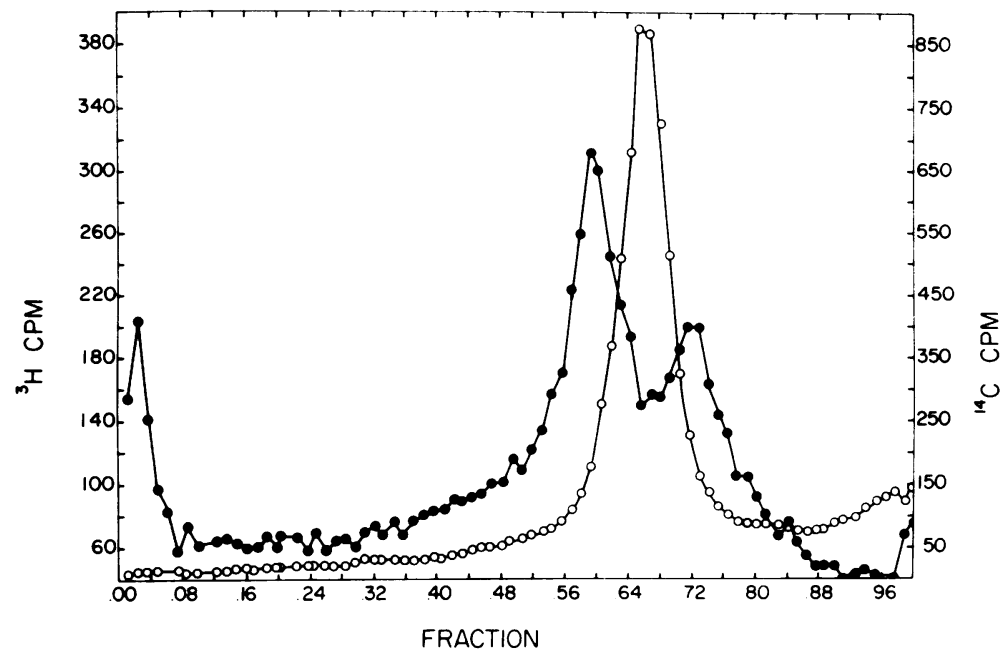

FIG. 11. Ascorbate control gradient. A 40-min intracellular DNA sample was incubated at 37 C for 45 min, layered onto a 10 to $20 \%$ linear sucrose gradient, and then centrifuged for $5.5 \mathrm{hr}$ at $37 \mathrm{C}$ in a Spinco SW-39 rotor. Fractions were collected and assayed for radioactivity. Symbols:,${ }^{3} \mathrm{H}$-labeled intracellular DNA components; $O,{ }^{14} \mathrm{C}$-labeled $\phi X 174$ am3 single-stranded DNA marker.

sample in the presence of ethidium bromide gave the results shown in Fig. 12B. Much of the "heavy" component was converted to "light" component by this treatment, as would be expected if a closed-circular, double-stranded DNA molecule were converted to a nicked-circular, double-stranded molecule by single-strand breaks.

Effect of heat denaturation on M-13-associated DNA components. Additional evidence that component II was a nicked double-stranded circular ring was obtained by heat denaturation. For this experiment, a DNA sample was used which contained a large amount of component II. This DNA sample was obtained in the following manner. E. coli $\mathrm{HfrH}$ strain 5 (temperature-sensitive in DNA synthesis), obtained from Fredrick Bonhoeffer, was infected at the permissive temperature $(35 \mathrm{C})$ by the addition of phage at a multiplicity of infection of 10 . The phage and the host cells were grown together for $2 \mathrm{hr}$ in the medium of Maaløe and Hanawalt (15) supplemented with Casamino Acids and $40 \mu \mathrm{g}$ of thymine per $\mathrm{ml}$. The cells were centrifuged, washed, and suspended in the presence of $10 \mu \mathrm{c}$ of thymine per $\mathrm{ml}$ at $42 \mathrm{C}$. (At this temperature, host-cell DNA synthesis ceases and incorporation of ${ }^{3} \mathrm{H}$-thymine into uninfected cells is less than $3 \%$ of the incorporation into infected cells. Cell samples were removed at various times and the DNA was extracted with phenol. When subjected to sucrose sedimentation analysis in $0.118 \times$ $\mathrm{SSC}$, the 30-min sample showed the tritium profile illustrated in Fig. 13. The large amount of component II observed was not unique to this gradient, since one other DNA sample of 19 analyzed showed a similar distribution of counts. The large amount of component II was probably due to single-strand breaks introduced during extraction. Part of this sample was heated to $93 \mathrm{C}$ for 4 min and rapidly chilled in an ice bath. Sedimentation analysis of this sample gave the results illustrated in Fig. 14. Component I was affected only slightly by the heat treatment, whereas almost all of component II was converted to single-strand DNA.

Synthesis of M-13 components I and II. Sufficient incorporation of ${ }^{3} \mathrm{H}$-thymine occurred in infected mitomycin C-treated cells so that both components could be detected 12 min after the cells were suspended in prewarmed $\mathrm{KC}$ broth. The total amount of the two components increased with time (Fig. 15 and 16), and the ratio of counts in component II to those in component I was usually about $0.11: 0.20$. In 2 of 19 samples this ratio was considerably higher. Samples removed early in infection showed a third component (Fig. 15A), but by $45 \mathrm{~min}$ (Fig. 16A) this component was no longer detected. In some samples removed between 45 and 90 min (Fig. 16B), a small DNA component was observed at the position of single-stranded DNA. An increase in the amount of components I and II between 45 and 90 min was observed, although phage synthesis ceased $60 \mathrm{~min}$ after suspension of infected cells in the radioactive medium. 

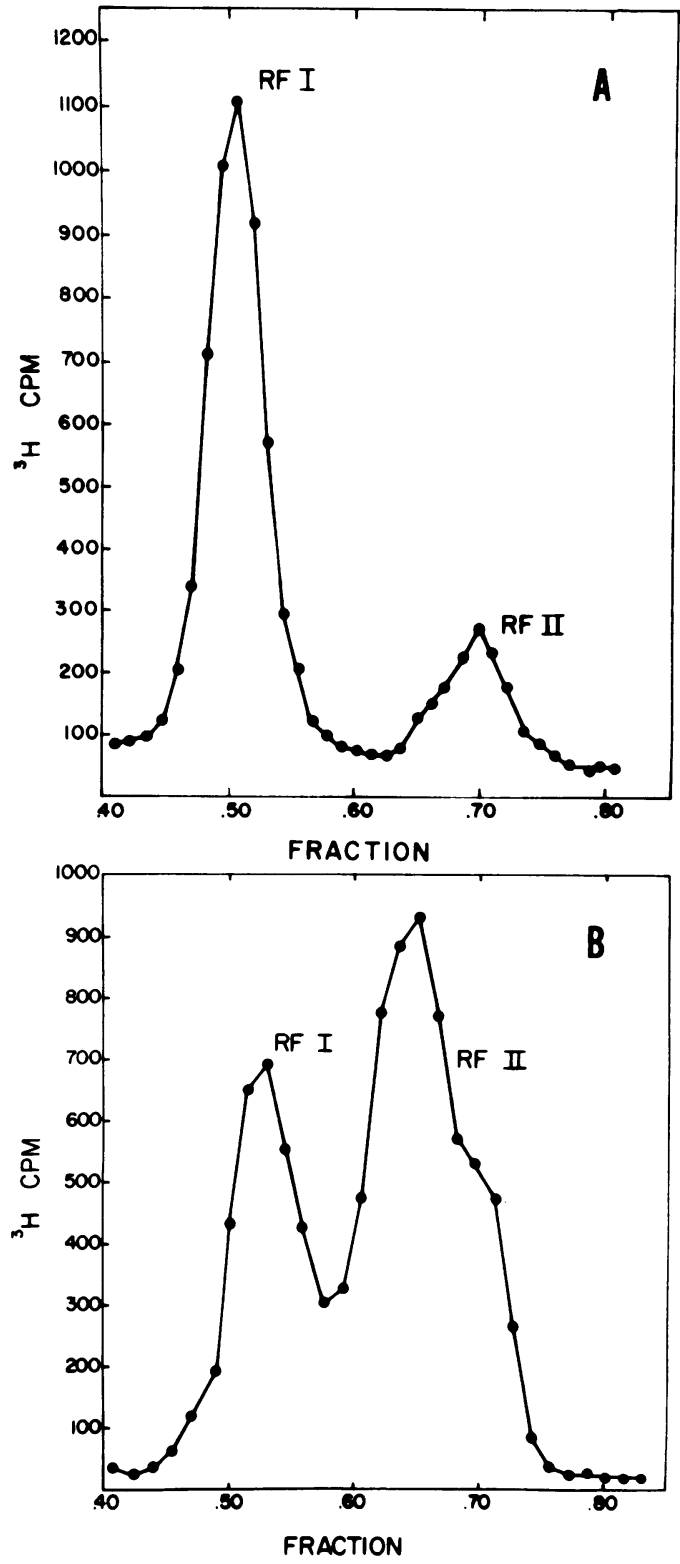

FIG. 12. CsCl equilibrium density gradient centrifugation of intracellular DNA in the presence of ethidium bromide. (A) A 500-uliter amount of a 15-min intracellular DNA sample from infected cells was added to an SSC-CsCl solution (mean density $=1.558 \mathrm{~g} / \mathrm{ml}$ ), containing $100 \mu \mathrm{g}$ of ethidium bromide per $\mathrm{ml}$, and was centrifuged for $30 \mathrm{hr}$ in a Spinco $S W-39$ rotor at 37,000 rev/min. Fractions were collected and assayed for radioactivity in a liquid scintillation spectrometer. $(B)$ A 750-pliter amount of the 15-min sample described in (A) was treated for $60 \mathrm{~min}$ at $37 \mathrm{C}$ with $7 \times 10^{-5} \mathrm{M}$ ascorbate. This was added to an SSC-CsCl solution (final mean density $=1.558 \mathrm{~g} / \mathrm{ml}$ ), containing 100

\section{Discussion}

Mitomycin C rapidly reduced the ability of the starved cells to form colonies, an effect not reversed by incubating the cells in broth. Upon infection, treated cells produced significant amounts of phage, but this system showed some pecularities. Firstly, starved treated cells ceased phage production $60 \mathrm{~min}$ after resuspension in $\mathrm{KC}$ broth, but incorporation into phage-specific DNA components I and II continued for at least an additional $30 \mathrm{~min}$. It is possible that mitomycin treatment eventually leads to the dissociation of ribosomes, as suggested by Suzuki and Kilgore (24). This would affect protein synthesis immediately but might not directly inhibit continued phage-directed DNA synthesis. Secondly, when cells were grown in minimal TPG or KC broth media, treated with ritomycin $\mathrm{C}$, and then suspended in minimal medium or TPG, phage synthesis was inhibited. Only when cells were grown in $\mathrm{KC}$ broth and resuspended in $\mathrm{KC}$ broth did we observe phage production. The failure of treated cells to produce phage upon shifts in medium was not surprising since the cells were under physiologically stressed conditions, but it is difficult to understand why cells grown in minimal or TPG broth and resuspended in the same media failed to produce phage.

The sucrose density gradient sedimentation profiles of intracellular tritium-labeled DNA samples, obtained at various times after M-13 infection of treated cells, revealed a total of four components. Components I and II have been shown to have properties comparable to the closed, double-stranded circular DNA or RF I, and the nicked, double-stranded, circular DNA or RF II of $\phi X 174$. Evidence for these types of configurations is based on the correlation of results obtained from (i) sucrose gradient sedimentation, (ii) the conversion of component I to II by ascorbate treatment, (iii) heat denaturation of component II to give single strands, (iv) the radioactivity profile of the labeled components in density equilibrium centrifugation in the presence of ethidium bromide, and (v) the density of the components relative to single-stranded DNA in $\mathrm{CsCl}$ at neutral $p \mathrm{H}$. In most of the DNA samples studied, the amount of DNA in component II was 10 to $15 \%$ of that found in component I. It is possible that these components may be involved in DNA replication in a manner similar to the RF I and RF II components of $\phi$ X174 (10, 11, 14), but their biological significance has not been

$\mu \mathrm{g}$ of ethidium bromide per $\mathrm{ml}$, and was centrifuged for $30 \mathrm{hr}$ in a Spinco $S W-39$ rotor at 37,000 rev/min. Fractions were collected and assayed for radioactivity. 
demonstrated. We cannot exclude the possibility that the RF II present is an artifact of DNA sample preparation.

The other two components were not analyzed extensively. The third component appeared only in samples removed early after phage development was initiated. This component sedimented more slowly than did either RF I or RF II. Its relative sedimentation rate would indicate a low molecular weight molecule.

The fourth component, which had the sedimentation properties of single-stranded DNA, was present in samples extracted 45 to 90 min after phage infection. It was also present in samples

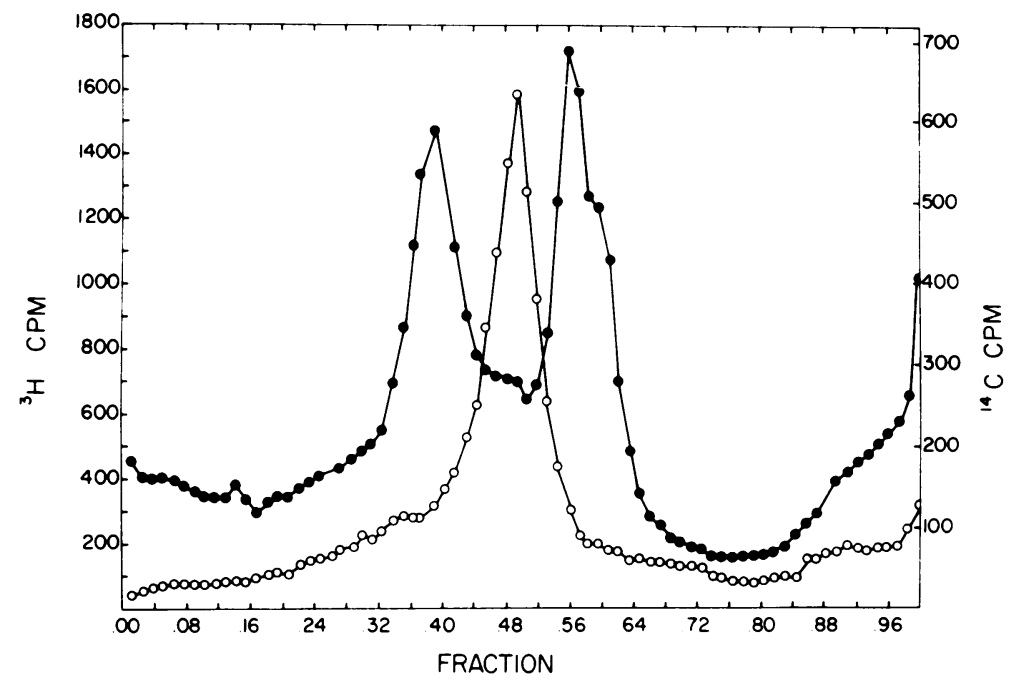

FIG. 13. Sedimentation of an intracellular DNA sample containing a large RF II component. Intracellular DNA was isolated from M-13-infected culture of E. coli HfrH ts DNA, Bonhoeffer strain 5; 30 min later, these cells were suspended in a medium containing ${ }^{3} \mathrm{H}$-thymine at the restrictive temperature for host-cell DNA synthesis. The DNA sample (100 uliter) was layered onto a 5 to $20 \%$ linear sucrose gradient under standard conditions with a ${ }^{14} \mathrm{C} \phi X 174$ am 3 marker and spun for $5.5 \mathrm{hr}$ in a Spinco $S W-39$ rotor at 37,000 rev/min; then the gradient was collected and assayed for radioactivity. Symbols: O, ${ }^{3} \mathrm{H}$-labeled intracellular DNA components; $\mathrm{O},{ }^{1+} \mathrm{C}$-labeled $\phi X 174$ am3 single-stranded DNA marker.

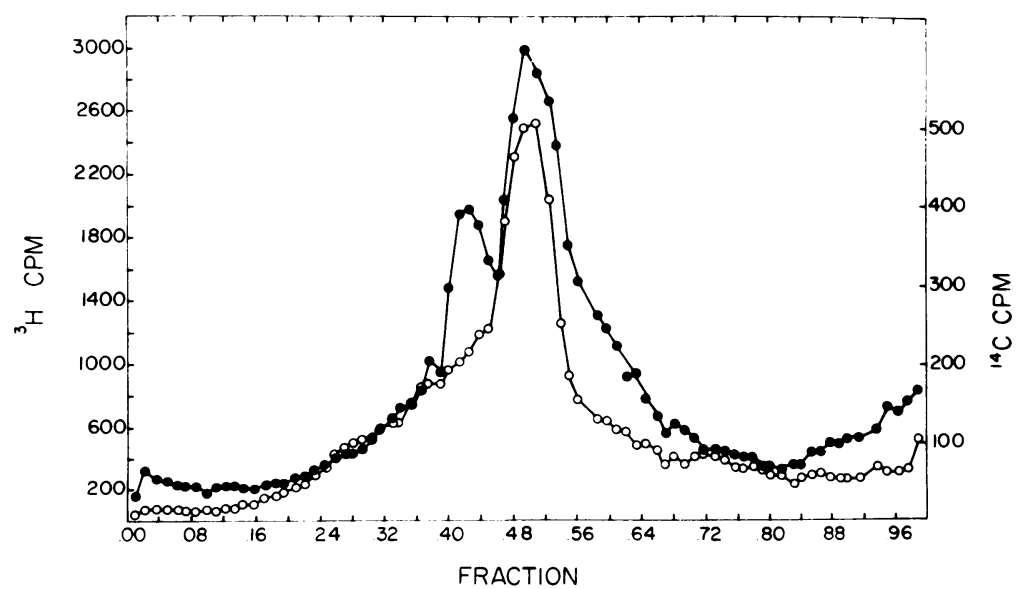

FIG. 14. Heat denaturation of component II. A portion of the sample described in Fig. 13 was heated to 93 C for 4 min and rapidly cooled in an ice bath. A 100 uliter amount of this DNA was layered onto a 5 to $20 \%$, linear sucrose gradient under standard conditions with a ${ }^{14}$ C-labeled $\phi X 174$ am 3 single-stranded DNA marker, spun at $37,000 \mathrm{rev} / \mathrm{min}$ in a Spinco $S W-39$ rotor for $5.5 \mathrm{hr}$, and then fractionated and assayed for radioactivity. Symbols:

. ${ }^{3} \mathrm{H}$-labeled intracellular DNA components; $\bigcirc,{ }^{14} \mathrm{C}$-labeled $\phi X 174$ am 3 single-stranded DNA marker. 


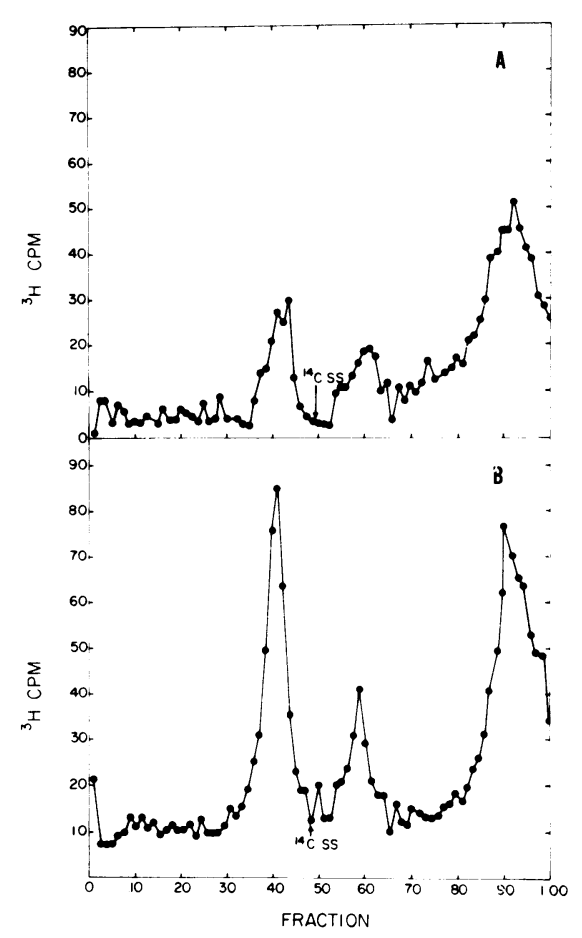

FIG. 15. Sedimentation analysis of 12- and 20-min intracellular DNA samples. Intracellular ${ }^{3} \mathrm{H}$-labeled DNA samples (100 uliters/gradient) and 25 uliters of ${ }^{14} C$-labeled $\phi X 174$ am 3 single-stranded $D N A$ were layered onto 5 to $20 \%$ linear sucrose gradients under standard ionic conditions $(0.118 \times S S C)$ and centrifuged at 37,000 rev/min in a Spinco $S W-39$ rotor for $5.5 \mathrm{hr}$. Fractions were collected and assayed for radioactivity. The position of the single-stranded marker peak is indicated. (A) A 12-min sample; (B) a 20-min sample.

treated with ascorbate and was probably composed of a mixture of viral DNA and its complementary strand, because most of this component was produced by denaturing RF II molecules. The single-stranded DNA detected in samples 45 to $90 \mathrm{~min}$ after infection could represent the DNA pool suggested by Ray et al. (19). The characterization of these molecules as circular or linear viral DNA or viral complementary strands could give additional information about their role in $\mathrm{M}-13$ replication.

The "late" DNA samples conained more tritium at the bottom of the sedimentation profile than was present in "early" time samples (removed before $30 \mathrm{~min}$ ). Host cell DNA could be observed in this area, but whether these counts represented residual host-cell DNA synthesis or material of viral origin was not known. The amount of the four components per infected cell could not be estimated directly since $\mathrm{KC}$ broth

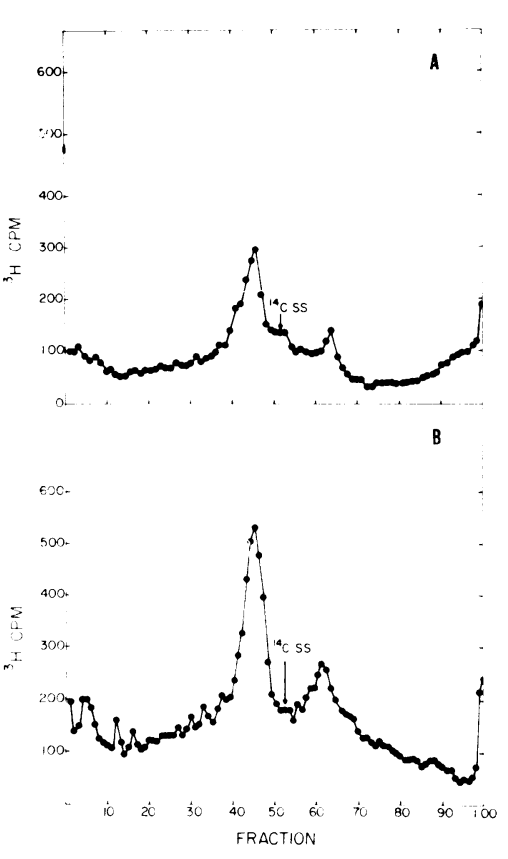

FIG. 16. Sedimentation analysis of 45- and 40-min intracellular DNA samples. Analysis of 45-min and 40-min samples was identical to that described in Fig. 15. (A) The 45-min sample; (B) 90-min sample.

contains some endogenous thymine, which complicates specific activity calculations. However, the relative ratio of single-stranded to doublestranded molecules was considerably less than that obtained by Ray et al. (19) from optical density measurements of intracellular DNA fractions eluted from a methylated albumin-kieselguhr column. This may reflect differences in sample preparation or the times chosen for sampling, but we think that it is unlikely that the ratio reflects an artifact of the mitomycin technique, since experiments with Bonhoeffer strain 5, using a temperature shift (to inhibit host-cell DNA synthesis), gave similar results.

From the analysis of sucrose sedimentation profiles of DNA present in intracellular extracts of M-13-infected cells, it was not possible to determine the role of the DNA components present in the replication of $\mathbf{M}-13$. However, it is evident from the amount of RF I and RF II present at various times after infection that net RF synthesis occurs during an active period of single-strand production. In contrast, net RF synthesis in $\phi \mathrm{X} 174$-infected cells ceases 15 to 20 min after infection, coincident with the initiation of single-strand synthesis (14).

\section{ACKNOWLEDGMENTS}

This investigation was supported by Public Health Service grants AI 07657 and AI 06389 from the 
National Institute of Allergy and Infectious Diseases, by Public Health Service Fellowship 5-F1-GM-30, 403-03 from the National Institute of General Medical Sciences, and by National Science Foundation grant GB-7264.

\section{Literature Cited}

1. Bode, V. C. 1967. Single-strand scissions induced in circular and linear $\lambda$ DNA by the presence of dithiothreitol and other reducing agents. J. Mol. Biol. 26:125-129.

2. Brown, L. R., and C. E. Dowell. 1968. Replication of coliphage M-13. I. Effects on host cells after synchronized infection. J. Virol. 2:12901295.

3. Burton, A., and R. L. Sinsheimer. 1965. The process of infection with bacteriophage $\phi \times 174$. VII. Ultracentrifugal analysis of the replicative form. J. Mol. Biol. 14:327-347.

4. Denhardt, D. T., and R. L. Sinsheimer. 1965. The process of infection with bacteriophage $\phi \times 174$. III. Phage maturation and lysis after synchronized infection. J. Mol. Biol. 12:641-646.

5. Dowell, C. E., and R. L. Sinsheimer. 1966. The processes of infection with bacteriophage $\phi X 174$. IX. Studies on the physiology of three $\phi X 174$ temperature-sensitive mutants. J. Mol. Biol. 16:374-386.

6. Garen, A., and O. Siddiqi. 1962. Suppression of mutations in the alkaline phosphate structural cistron of E. coli. Proc. Natl. Acad. Sci. U.S. 53:1121-1127.

7. Gutherie, G. D., and R. L. Sinsheimer. 1963. Observations on the infection of bacterial protoplasts with the deoxyribonucleic acid of bacteriophage $\phi \times 174$. Biochim. Biophys. Acta 72:290-297.

8. Hofschneider, P. H. 1963. Untersuchungen über, ,kleine" E. coli K12 Bakteriophagen. Z. Naturforsch. 18b:203-210.

9. Kleinschmidt, A. K., A. Burton, and R. L. Sinsheimer. 1963. Electron microscopy of the replication form of the DNA of bacteriophage $\phi X 174$. Science 142:961.

10. Knippers, R., T. Komano, and R. L. Sinsheimer. 1968. Process of infection with bacteriophage $\phi X 174$. XXI. Replication and fate of the replicative form. Proc. Natl. Acad. Sci. U.S. 59:577582.

11. Komano, T., R. Knippers, and R. L. Sinsheimer. 1968. Process of infection with bacteriophage $\phi X 174$. XXII. Synthesis of progeny singlestranded DNA. Proc. Natl. Acad. Sci. U.S. 59:911-916.

12. Lindqvist, B. H., and R. L. Sinsheimer. 1967. Process of infection with bacteriophage $\phi \times 174$. XIV. Studies on macromolecular synthesis during infection with a lysis-defective mutant. J. Mol. Biol. 28:87-94.
13. Lindqvist, B. H., and R. L. Sinsheimer. 1967. The process of infection with bacteriophage $\phi \times 174$. XV. Bacteriophage DNA synthesis in abortive infections with a set of conditional lethal mutants. J. Mol. Biol. 30:69-80.

14. Lindqvist, B. H., and R. L. Sinsheimer. 1968. The process of infection with bacteriophage $\phi \times 174$. XVI. Synthesis of the replicative form and its relationship to viral single-stranded DNA synthesis. J. Mol. Biol. 32:285-302.

15. Maalфe, O., and P. C. Hanawalt. 1961. Thymine deficiency and the normal DNA replication cycle I. J. Mol. Biol. 3:144.

16. Marvin, D. A., and H. Shaller. 1966. The topology of DNA from the small filamentous bacteriophage fd. J. Mol. Biol. 15:1-7.

17. Nakanishi, H., Y. Iida, K. Maeshima, T. Teramoto, Y. Hosaka, and M. Ozaki. 1966. Isolation and properties of bacteriophages of Vibrio parahaemolyticus. Biken J. 9:149-157.

18. Radloff, R., W. Bauer, and J. Vinograd. 1967. A dye-buoyant-density method for the detection and isolation of closed circular duplex DNA: the closed circular DNA in Hela cells. Proc. Natl. Acad. Sci. U.S. 57:1514-1521.

19. Ray, D. S., H. P. Bscheider, and P. H. Hofschneider. 1966. Replication of the singlestranded DNA of the male-specific bacteriophage M13. Isolation of intracellular forms of phage-specific DNA. J. Mol. Biol. $21: 473-483$.

20. Ray, D. S., A. Preuss, and P. H. Hofschneider. 1966. Replication of the single-stranded DNA of the male-specific bacteriophage M13. Circular forms of the replicative DNA. J. Mol. Biol. 21 : $485-491$.

21. Salivar, O., H. Tzagoloff, and D. Pratt. 1964. Some physical-chemical and biological properties of the rod-shaped coliphage M13. Virology 24:359-371.

22. Sedat, J., and R. L. Sinsheimer. 1965. The process of infection with bacteriophage $\phi \times 174$. V. Purine sequences. J. Mol. Biol. 9:489-497.

23. Sinsheimer, R. L., B. Storman, C. Nagler, and S. Gutherie. 1962. The process of infection with bacteriophage $\phi$ X174. I. Evidence for a "replicative form." J. Mol. Biol. 4:142.

24. Suzuki, H., and W. W. Kilgore. 1967. Decomposition of ribosomal particles in Escherichia coli treated with mitomycin C. J. Bacteriol. 94: 666-676.

25. Takeya, K., and K. Amako. 1966. A rod-shaped Pseudomonas phage. Virology 28:163-164.

26. Tzagoloff, H., and D. Pratt. 1964. The initial steps in infection with coliphage M13. Virology 24: 372-380.

27. Vinograd, J., J. Lebowitz, R. Radloff, R. Watson, and P. Laipis. 1965. The twisted circular form of polyoma viral DNA. Proc. Natl. Acad. Sci. U.S. 53:1104-1111. 